\title{
Profile of Essential Oils From the Leaves of Annona Grafted
}

\author{
Felipe G. Campos ${ }^{1}$, Maria A. R. Vieira ${ }^{1}$, Daniel Baron ${ }^{2}$, Marcia O. M. Marques ${ }^{3}$, \\ Gisela Ferreira $^{1} \&$ Carmen S. F. Boaro ${ }^{1}$ \\ ${ }^{1}$ Departamento de Botânica, Instituto de Biociências, Universidade Estadual Paulista, Campus de Botucatu, \\ Botucatu, São Paulo, Brasil \\ ${ }^{2}$ Centro de Ciências da Natureza, Departamento Acadêmico Lagoa do Sino, Universidade Federal de São Carlos, \\ São Paulo, Brazil \\ ${ }^{3}$ Centro de Pesquisa e Desenvolvimento de Recursos Genéticos Vegetais, Instituto Agronômico, Campinas, São \\ Paulo, Brazil \\ Correspondence: Carmen S. F. Boaro, Departamento de Botânica, Universidade Estadual Paulista, Campus de \\ Botucatu, R. Prof. Dr. Antonio Celso Wagner Zanin, s/nº Botucatu, 18618-689, São Paulo, Brazil. Tel: \\ 55-143-880-0124. E-mail: carmen.boaro@unesp.br
}

Received: October 15, 2018

Accepted: November 16, 2018

Online Published: January 15, 2019

doi:10.5539/jas.v11n2p210

URL: https://doi.org/10.5539/jas.v11n2p210

\begin{abstract}
Mechanical damage, during grafting, results in the formation of reactive oxygen species, which are neutralized by the enzymatic and non-enzymatic antioxidant systems which may influence the essential oil composition of grafts and rootstocks because of the formation of oxygenated terpenes, substances with higher reactivity against pathogens. Various studies have demonstrated the biological activity of Annonaceae and the important pharmacological potential of the substances produced by the genus Annona. Thus, we studied the essential oils of leaves collected from the graft (Annona $\times$ atemoya) and lateral budding from the rootstock (Annona emarginata), in the same individual, in order to characterize chemical profile. The extraction was carried out by hydrodistillation and separation, quantification and identification of the substances were performed by gas chromatography coupled to a mass spectrometer. Chemical profiles of essential oils were evaluated by principal component analysis (PCA). Annona $\times$ atemoya and Annona emarginata presented chemical profiles of essential oil with specific substances. Some substances are common in oils of both species. Germacrene D is predominant in Annona $\times$ atemoya and $\alpha$ and $\beta$-selinene, $\beta$-elemene and spathulenol occurred in Annona emarginata. Our results suggest that the profile of such essential oil may be another indicator for the success of the combination of these two species.
\end{abstract}

Keywords: Annona emarginata (Schltdl.) H. Rainer 'araticum-de-terra-fria', atemoya, specialized metabolism, oxygenated terpene, terpenes

\section{Introduction}

The Annonaceae family has the important genus Annona, mainly because of its edible fruits. Several studies have demonstrated in Annona biological activity of substances, which have important pharmacological potential (Boyom et al., 2011; Fontes et al., 2013; D. M. S. Ocampo \& R. C. Ocampo, 2006; Siqueira et al., 2011).

Essential oils are substances produced by specialized metabolism and are characterized by the odor they produce. Essential oils are predominantly made up of terpenes (monoterpenes and sesquiterpene (Bakkali, Averbeck, Averbeck, \& Idaomar, 2008).

In nature, essential oils provide important defense functions in plants, such as bactericidal, antiviral, antifungal, insecticidal, and repellent. Essential oils are also important for attracting pollen (pollinators) and seed dispersal agents (Bakkali et al., 2008; Edris, 2007; Rivoal et al., 2010) and are involved in signaling among plants (Laothawornkitkul, Taylor, Paul, \& Hewitt, 2009).

Annona $\times$ atemoya Thompson variety presents susceptibility to stem borers (Baron, Amaro, Pina, \& Ferreira, 2019), and its cultivation depends on grafting it on Annona emarginata (Schltdl.) H. Rainer, araticum-de-terra-fria, which has the potential of a rootstock, thereby providing required resistance. 
The grafting process results in transferring molecules, such as mRNAs, between the rootstock and scion, which may interfere in the synthesis of other molecules involved in the primary (Baron et al., 2019; Baron, Bravo, Maia, Pina, \& Ferreira, 2016; Kanehira et al., 2010) and specialized metabolisms, as essential oils.

The great susceptibility of atemoya to pathogens is controlled by means of grafting on A. emarginata, whose resistance (Baron et al., 2019) may be related, at least in part, to biosynthesized substances in the specialized metabolism, such as terpenes, which are present in essential oils.

Thus, we studied the essential oils of leaves collected from the graft (Annona $\times$ atemoya) and lateral budding of the rootstock (Annona emarginata), in the same individual, in order to characterize the chemical profile.

\section{Materials and Methods}

\subsection{Plant Material}

Annona $\times$ atemoya plants were grafted onto Annona emarginata (Schltdl.) H. Rainer variety of terra-fria in commercial crop. Although productivity was guaranteed, among other factors, by the removal of lateral budding of the rootstock, in this study the leaves of these shoots were collected, which allowed the study of the essential oil of the graft and rootstock in the same individual under the same conditions.

The plant material was collected on Paraizinho farm in the city of Pardinho, São Paulo, Brazil $\left(23^{\circ} 5^{\prime} 3^{\prime \prime}\right.$ S, $48^{\circ} 22^{\prime} 38^{\prime \prime} \mathrm{W} ; 895 \mathrm{~m}$ above sea level). The collection was conducted during late spring between 9:30 AM and 10:00 AM. Subsequently, the leaves were dried at $40{ }^{\circ} \mathrm{C}$ to a constant dry weight.

\subsection{Oil Extraction and Analysis}

After drying, $80 \mathrm{~g}$ dry masses of the leaves of the two species were hydro-distillized for $2 \mathrm{~h}$ to have essential oils extracted in a Clevenger-type apparatus. Essential oils were separated from the aqueous phase using the solvent dichloromethane $\left(0.5 \mathrm{~mL}, \mathrm{Merck}^{\circledR}\right)$. The extracted oils were stored in amber glass vials at $-20{ }^{\circ} \mathrm{C}$ prior to the analysis of their chemical composition (Campos, Baron, Marques, Ferreira, \& Boaro, 2014).

\subsection{GC-MS Analysis}

The separation, quantification, and identification of essential oils were performed using a gas chromatograph coupled to a mass spectrometer (CG-MS, Shimadzu ${ }^{\circledR}$, QP-5000) with an electron impact (70 eV) and a capillary column of fused silica OV-5 [Ohio 'Valley Specialty Chemical ${ }^{\circledR}$, Inc. $30.0 \mathrm{~m} \times 0.25 \mathrm{~mm} \times 0.25 \mu \mathrm{m}$; carrier gas, helium (flow rate, $1 \mathrm{~mL} \mathrm{~min}{ }^{-1}$ ); injection temperature, $230{ }^{\circ} \mathrm{C}$; detector temperature, $240{ }^{\circ} \mathrm{C}$; and split ratio, $1 / 20)$. It was injected $1 \mu \mathrm{L}$ solution $(1 \mu \mathrm{L}$ of essential oils in $1 \mathrm{~mL}$ ethyl acetate, with the following temperature program: $60-240{ }^{\circ} \mathrm{C}, 3^{\circ} \mathrm{C} / \mathrm{min}$ (Campos et al., 2014).

The compounds were identified by comparing the obtained mass spectra with the database system GC-MS (Nist. 62 lib.), literature (Adams, 2007), and retention index (RI). In order to obtain RI of the substances, a mixture of $n$-alkanes $\left(\mathrm{C}_{9}-\mathrm{C}_{24}\right.$; Sigma Aldrich $\left.{ }^{\circledR} 99 \%\right)$ was employed and analyzed under the same operating conditions of samples, and the equation by Van den Dool \& Kratz (Van Den Dool \& Kratz 1963) were used.

\subsection{Statistical Analysis}

Principal component analysis (PCA) was carried out with the substances presented in the essential oil using XLSTAT program (2017).

\section{Results and Discussion}

Substances classified as monoterpene hydrocarbons, oxygenated monoterpenes, sesquiterpene hydrocarbons, and oxygenated sesquiterpenes were identified in essential oils of both species, all of them from terpenes class (Table 1).

Sesquiterpenes were predominant in essential oils, while sesquiterpene hydrocarbons and oxygenated sesquiterpenes constituted by $90.1 \%$ and $72.9 \%$ of essential oils of atemoya and A. emarginata, respectively.

Monoterpenes are highly affected by temperature and luminous intensity, and thus, can be volatilized (Bakkali et al., 2008; Wang, Owen, Li, \& Peñuelas, 2007). The percentage difference of sesquiterpenes observed in both species, which was higher in atemoya, may be due to the crown of atemoya and was more exposed to light and temperature. Atemoya was grafted on A. emarginata, whose collected lateral budding (thief branch) was more protected from light and temperature.

The multivariate analysis revealed that the rootstock species (A. emarginata) and graft (Annona $\times$ atemoya) presented oils with major substances, characterizing two different groups of chemical profiles. A. emarginata was mainly discriminated by $\alpha$ and $\beta$-selinene, $\beta$-elemene and spathulenol, totalizing $41.75 \%$ and Annona $\times$ 
atemoya by germacrene D (42.82\%) (Figure 1). Biotic factors have the potential to alter the chemical composition and production of essential oils in which the molecules are formed by the interaction between plants and environment (Dudareva, Klempien, Muhlemann, \& Kaplan, 2013; Holopainen \& Gershenzon, 2010).

Moreover, a high percentage of oxygenated terpenes in essential oils of atemoya (12.19\%) and A. emarginata $(20.14 \%)$ was identified, which may indicate stress, because the comparison between the chemical profiles of essential oils from the ungrafted rootstock $A$. emarginata, grown in a greenhouse, demonstrated the absence of oxygenated terpenes (Campos et al., 2014).

Thus, the mechanical damage resulting from grafting (Suzuki \& Mittler, 2012) may have been the cause of stress, leading to the formation of reactive oxygen species (ROS) (Suzuki \& Mittler, 2012). The increased production of oxygenated terpene fractions may have contributed to ROS neutralization by non-enzymatic antioxidant system (Gill \& Tuteja, 2010). Terpene oxygenates are molecules with high reactivity against pathogens (Oda, Fujinuma, Inoue, \& Ohashi, 2011), which may explain their high percentage in $A$. emarginata, which is used as the rootstock for atemoya. Moreover, the pathogen resistance in A. emarginata may originate from the union of the species with atemoya because terpene oxygenates were observed after grafting and have not been observed in non-grafted plants (Campos et al., 2014). Furthermore, the union of plants at different ages can be an additional reason for the increased ROS production.

After grafting, the evaluation of the essential oil composition of the leaves of atemoya variety Thompson identified 28 substances, of which germacrene D was the most abundant (42.8\%). In the essential oils extracted from $A$. emarginata, 36 substances were identified, with $\beta$-selinene $(12.6 \%)$ and $\alpha$-selinene $(12.2 \%)$ forming the major components (Table 1). Germacrene D is a sesquiterpene hydrocarbon that is related to ecological roles in the interaction of plants with their predators and pollinators (Prosser et al., 2004), functions as an attraction agent, and facilitates the location of plants for food and ovipositor. Sesquiterpenes, similar to pheromones, bind to the receptors located on the antennae of insects, as demonstrated in Heliothis virescens (Mozuraitis, Stranden, Ramirez, Borg-Karlson, \& Mustaparta, 2002; Skiri, Galizia, \& Mustaparta, 2004; Stranden et al., 2003).

High percentages of germacrene D were also found in Xylopia laevigata collected in the cities of Santa Luzia do Itanhy $\left(11^{\circ} 22^{\prime} 54^{\prime \prime} \mathrm{S}, 37^{\circ} 25^{\prime} 15^{\prime \prime} \mathrm{W}\right)$ and São Cristóvão $\left(10^{\circ} 55^{\prime} 08^{\prime \prime} \mathrm{S}, 37^{\circ} 06^{\prime} 13^{\prime \prime} \mathrm{W}\right)$ in Sergipe state $(60.44 \%$ and $43.62 \%$, respectively) (Quintans et al., 2013). The similarity of the essential oils of atemoya and X. laevigata collected in São Cristóvão should be noted. Three predominant substances in the essential oils have the following percentages: germacrene D $(42.82 \%-43.62 \%)$, bicyclogermacrene $(14.28 \%-14.63 \%)$, and $(E)$-caryophyllene (8.35\%-7.98\%). Sesquiterpenes, identified in the essential oils extracted from the atemoya pulp (Pino \& Rosado, 1999), may be indicative of the involvement of this substance in the attraction of animal seed dispersers. Study indicates possibilities for pest control from the study of sesquiterpenes (Prosser et al., 2004).

Several substances found in the essential oils of $A$. emarginata and atemoya variety Thompson (Table 1$)$ had biological activities and were not always extracted and isolated from Annonaceae. Therefore, $\alpha$-pinene, $\beta$-pinene (Medeiros Leite et al., 2007; Nissen, Zatta, Stefanini, Grandi, \& Sgorbati, 2010), limonene (Espina, Gelaw, de Lamo-Castellví, Pagán, \& García-Gonzalo, 2013), (E)-caryophyllene (Costa et al., 2008), and spathulenol (Limberger, Sobral, Henriques, Menut, \& Bessière, 2004) showed bactericidal activity. $\beta$-elemene and spathulenol showed cytotoxic activity (Wang et al., 2005; Yao et al., 2008), $\beta$-selinene showed insecticidal and antibacterial activity (Chu et al., 2011; Souza et al., 2017), and bicyclogermacrene showed fungicidal activity (Silva et al., 2007).

These substances demonstrated biological activity, which may be related to insect-plant interactions, including the attraction of insects and protection or defense of plants against pathogens, and operated as antioxidant non-enzymatic substances against oxidative stress. 
Table 1. Chemical composition (\%) of the essential oils of atemoya (Annona $\times$ atemoya) and Annona emarginata

\begin{tabular}{|c|c|c|c|c|}
\hline Substances & $\begin{array}{l}\text { Annona } \times \text { atemoya } \\
\text { (graft) }\end{array}$ & $\begin{array}{l}\text { Annona emarginata } \\
\text { (rootstock) }\end{array}$ & $\mathrm{RI}_{\mathrm{E}}$ & $\mathrm{RI}_{\mathrm{L}}$ \\
\hline & \multicolumn{4}{|c|}{ 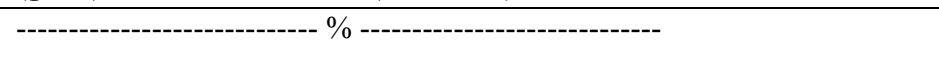 } \\
\hline \multicolumn{5}{|l|}{ Monoterpene hydrocarbons } \\
\hline$\alpha$-thujene & - & 0.52 & 927 & 930 \\
\hline$\alpha$-pinene & 2.62 & 5.55 & 934 & 939 \\
\hline Camphene & - & 0.52 & 949 & 954 \\
\hline$\beta$-pinene & 4.25 & 3.51 & 978 & 979 \\
\hline Mircene & $\operatorname{Tr}$ & 1.21 & 991 & 990 \\
\hline$p$-cymene & - & 0.74 & 1024 & 1024 \\
\hline Limonene & 0.92 & 4.84 & 1029 & 1029 \\
\hline trans- $\beta$-ocimene & 0.59 & $\operatorname{Tr}$ & 1047 & 1050 \\
\hline$\gamma$-terpinene & - & 0.68 & 1058 & 1059 \\
\hline \multicolumn{5}{|l|}{ Oxygenated monoterpene } \\
\hline 1,8 cineole & - & 2.68 & 1031 & 1031 \\
\hline Linalool & 0.94 & 1.43 & 1100 & 1096 \\
\hline terpinen-4-ol & - & 0.77 & 1177 & 1177 \\
\hline$\alpha$-terpineol & - & 2.44 & 1190 & 1188 \\
\hline \multicolumn{5}{|l|}{ Sesquiterpene hydrocarbons } \\
\hline$\delta$-elemene & 1.22 & $\mathbf{T r}$ & 1339 & 1338 \\
\hline$\alpha$-copaene & 0.72 & $\operatorname{Tr}$ & 1378 & 1376 \\
\hline$\beta$-boubonene & 0.61 & 2.70 & 1386 & 1388 \\
\hline$\beta$-cubebene & 1.49 & - & 1392 & 1388 \\
\hline$\beta$-elemene & 2.12 & 9.66 & 1394 & 1390 \\
\hline (E)-caryophyllene & 8.35 & 5.39 & 1421 & 1419 \\
\hline Aromadendrene & $\operatorname{Tr}$ & 4.36 & 1440 & 1441 \\
\hline$\alpha$-humulene & 1.94 & 0.52 & 1455 & 1454 \\
\hline$\beta$-chamigrene & - & 3.99 & 1477 & 1477 \\
\hline germacrene D & 42.82 & 0.66 & 1482 & 1485 \\
\hline$\beta$-selinene & - & 12.63 & 1487 & 1490 \\
\hline$\alpha$-selinene & $\operatorname{Tr}$ & 12.21 & 1496 & 1498 \\
\hline Bicyclogermacrene & 14.28 & - & 1496 & 1500 \\
\hline Germacrene A & 1.03 & $\mathbf{T r}$ & 1506 & 1509 \\
\hline$\gamma$-cadinene & $\operatorname{Tr}$ & 1.07 & 1515 & 1513 \\
\hline$\delta$-cadinene & 1.11 & 2.42 & 1525 & 1523 \\
\hline$\alpha$-cadinene & - & 0.74 & 1539 & 1538 \\
\hline Germacrene B & 3.16 & 3.71 & 1558 & 1561 \\
\hline \multicolumn{5}{|l|}{ Oxygenated sesquiterpenos } \\
\hline Elemol & 1.33 & Tr & 1550 & 1549 \\
\hline trans-nerolidol & 0.59 & $\operatorname{Tr}$ & 1564 & 1563 \\
\hline Spathulenol & 2.89 & 7.25 & 1578 & 1578 \\
\hline Caryophyllene oxide & 1.68 & 3.19 & 1584 & 1583 \\
\hline 1-epi-cupenol & 1.39 & $\operatorname{Tr}$ & 1621 & 1628 \\
\hline Cubenol & 1.47 & $\operatorname{Tr}$ & 1642 & 1646 \\
\hline$\alpha$-cadinol & 1.90 & 2.38 & 1654 & 1654 \\
\hline Monoterpene hydrocarbons & 8.38 & $\mathbf{1 7 . 5 7}$ & & \\
\hline Oxygenated Monoterpene & 0.94 & 7.32 & & \\
\hline Sesquiterpene hydrocarbons & 78.85 & 60.06 & & \\
\hline Oxygenated sesquiterpenes & 11.25 & 12.82 & & \\
\hline$\%$ Identification & 99.42 & 97.77 & & \\
\hline
\end{tabular}

Note. $\mathrm{RI}_{\mathrm{E}}=$ experimental retention index; $\mathrm{RI}_{\mathrm{L}}=$ literature retention index (Adams 2007); (-) = absence of substance; $\operatorname{tr}=$ trace $(\operatorname{tr} \leq 0.05)$. 


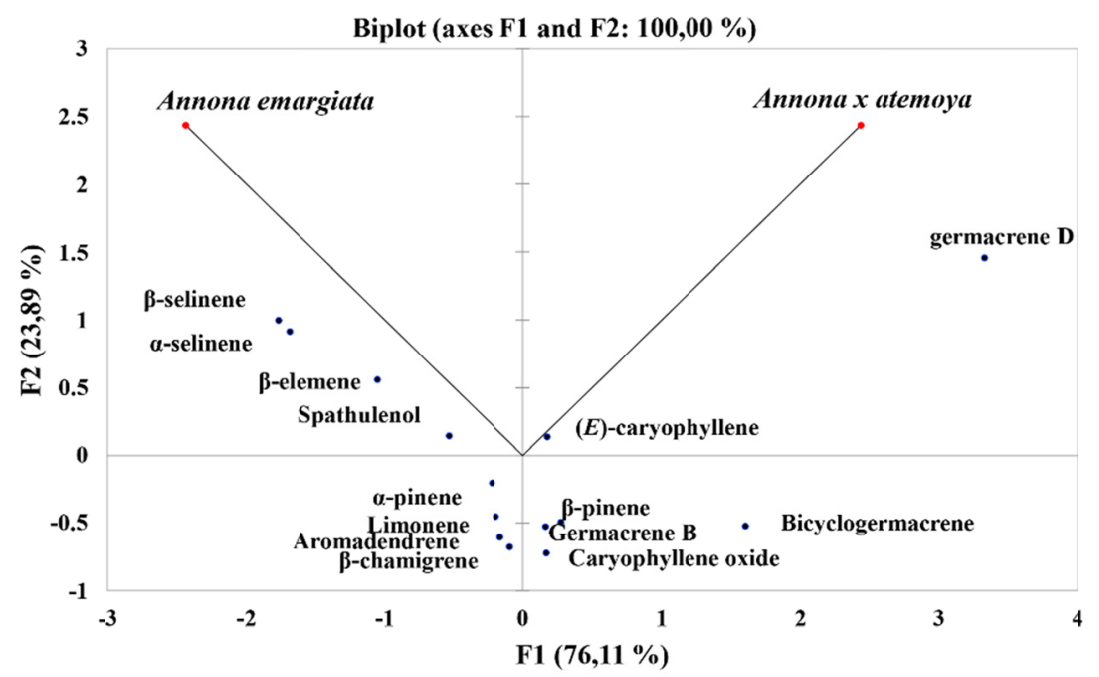

Figure 1. Principal components analysis (PCA) of the essential oil components of 14 of Annona $\times$ atemoya and Annona emarginata in Pardinho, São Paulo, Brazil

\section{Conclusion}

Annona $\times$ atemoya and Annona emarginata presented chemical profiles of essential oils with specific substances that may suggest plant-insect interaction and action on the resistance presented by the rootstock. Some substances are common in oils of both species. Our results suggest that the profile of the essential oil may be another indicator for the success of the combination of these two species.

\section{References}

Adams, R. P. (2007). In C. Stream (Ed.), Identification of essential oils components by gas chromatography/ mass spectroscopy (4th ed.). Allured Publishing Corporation.

Bakkali, F., Averbeck, S., Averbeck, D., \& Idaomar, M. (2008). Biological effects of essential oils-A review. Food and Chemical Toxicology: An International Journal Published for the British Industrial Biological Research Association, 46(2), 446-75. https://doi.org/10.1016/j.fct.2007.09.106

Baron, D., Amaro, A. C. E., Pina, A., \& Ferreira, G. (2019). An overview of grafting re-establishment in woody fruit species. Scientia Horticulturae, 243, 84-91. https://doi.org/10.1016/j.scienta.2018.08.012

Baron, D., Bravo, J. P., Maia, I. G., Pina, A., \& Ferreira, G. (2016). UGP gene expression and UDP-glucose pyrophosphorylase enzymatic activity in grafting annonaceous plants. Acta Physiologiae Plantarum, 38(3), 79. https://doi.org/10.1007/s11738-016-2097-7

Boyom, F. F., Fokou, P. V. T., Yamthe, L. R. T., Mfopa, A. N., Kemgne, E. M., Mbacham, W. F., ... Rosenthal, P. J. (2011). Potent antiplasmodial extracts from Cameroonian Annonaceae. Journal of Ethnopharmacology, 134(3), 717-724. https://doi.org/10.1016/j.jep.2011.01.020

Campos, F. G., Baron, D., Marques, M. O. M., Ferreira, G., \& Boaro, C. S. F. (2014). Characterization of the chemical composition of the essential oils from Annona emarginata (Schltdl .) H . Rainer ' terra-fria' and Annona squamosa L. 1. Revista Brasileira de Fruticultura, 36, 202-208. https://doi.org/10.1590/S0100-2 9452014000500024

Chu, S. S., Jiang, G. H., \& Liu, Z. L. (2011). Insecticidal compounds from the essential oil of Chinese medicinal herb Atractylodes chinensis. Pest Management Science, 67(10), 1253-7. https://doi.org/10.1002/ps.2180

Costa, E. V., Teixeira, S. D., Marques, F. A., Duarte, M. C. T., Delarmelina, C., Pinheiro, M. L. B., ... Sales Maia, B. H. L. N. (2008). Chemical composition and antimicrobial activity of the essential oils of the Amazon Guatteriopsis species. Phytochemistry, 69(9), 1895-1899. https://doi.org/10.1016/j.phytoch em.2008.03.005

Dudareva, N., Klempien, A., Muhlemann, J. K., \& Kaplan, I. (2013). Biosynthesis, function and metabolic engineering of plant volatile organic compounds. New Phytologist, 198(1), 16-32. https://doi.org/10.1111/ 
nph. 12145

Edris, A. E. (2007). Review of pharmacological effects of Glycyrrhiza radix and its bioactive compounds. Phytotherapy Research, 21, 308-323. https://doi.org/10.1002/ptr.2072

Espina, L., Gelaw, T. K., de Lamo-Castellví, S., Pagán, R., \& García-Gonzalo, D. (2013). Mechanism of bacterial inactivation by $(+)$-limonene and its potential use in food preservation combined processes. PloS One, 8(2), e56769. https://doi.org/10.1371/journal.pone.0056769

Fontes, J. E. do N., Ferraz, R. P. C., Britto, A. C. S., Carvalho, A. A., Moraes, M. O., Pessoa, C., ... Bezerra, D. P. (2013). Antitumor effect of the essential oil from leaves of guatteria pogonopus (Annonaceae). Chemistry and Biodiversity, 10(4), 722-729. https://doi.org/10.1002/cbdv.201200304

Gill, S. S., \& Tuteja, N. (2010). Reactive oxygen species and antioxidant machinery in abiotic stress tolerance in crop plants. Plant Physiology and Biochemistry, 48(12), 909-930. https://doi.org/10.1016/j.plaphy.201 0.08 .016

Holopainen, J. K., \& Gershenzon, J. (2010). Multiple stress factors and the emission of plant VOCs. Trends in Plant Science, 15(3), 176-184. https://doi.org/10.1016/j.tplants.2010.01.006

Kanehira, A., Yamada, K., Iwaya, T., Tsuwamoto, R., Kasai, A., Nakazono, M., \& Harada, T. (2010). Apple phloem cells contain some mRNAs transported over long distances. Tree Genetics and Genomes, 6(5), 635-642. https://doi.org/10.1007/s11295-010-0279-9

Laothawornkitkul, J., Taylor, J. E., Paul, N. D., \& Hewitt, C. N. (2009). Biogenic volatile organic compounds in the Earth system. The New Phytologist, 183(1), 27-51. https://doi.org/10.1111/j.1469-8137.2009.02859.x

Limberger, R. P., Sobral, M., Henriques, A. T., Menut, C., \& Bessière, J.-M. (2004). Óleos voláteis de espécies de Myrcia nativas do Rio Grande do Sul. Química Nova, 27(6), 916-919. https://doi.org/10.1590/S010040422004000600015

Medeiros Leite, A., de Oliveira Lima, E., Leite de Souza, E., de Fátima Formiga Melo Diniz, M., Nogueira Trajano, V., \& Almeida de Medeiros, I. (2007). Inhibitory effect of $\beta$-pinene , $\alpha$-pinene and eugenol on the growth of potential infectious endocarditis causing Gram-positive bacteria. Revista Brasileira de Ciências Farmacêuticas, 43, 121-126. https://doi.org/10.1590/S1516-93322007000100015

Mozuraitis, R., Stranden, M., Ramirez, M. I., Borg-Karlson, A-K., \& Mustaparta, H. (2002). (-)-Germacrene D increases attraction and oviposition by the tobacco budworm moth Heliothis virescens. Chemical Senses, 27(6), 505-9. https://doi.org/10.1093/chemse/27.6.505

Nissen, L., Zatta, A., Stefanini, I., Grandi, S., \& Sgorbati, B. (2010). Characterization and antimicrobial activity of essential oils of industrial hemp varieties (Cannabis sativa L.). Fitoterapia Journal, 81, 413-419. https://doi.org/10.1016/j.

Ocampo, D. M. S., \& Ocampo, R. C. (2006). Bioactividad de la familia Annonaceae. Revista Universidad Caldas, 12, 135-155.

Oda, S., Fujinuma, K., Inoue, A., \& Ohashi, S. (2011). Synthesis of (-)- $\beta$-caryophyllene oxide via regio- and stereoselective endocyclic epoxidation of $\beta$-caryophyllene with Nemania aenea SF $10099-1$ in a liquid-liquid interface bioreactor (L-L IBR). Journal of Bioscience and Bioengineering, 112(6), 561-565. https://doi.org/10.1016/j.jbiosc.2011.07.024

Pino, J. A., \& Rosado, A. (1999). Volatile Constituents of Custard Apple (Annona atemoya). Journal of Essential Oil Research, 11(3), 303-305. https://doi.org/10.1080/10412905.1999.9701139

Prosser, I., Altug, I. G., Phillips, A. L., König, W. A., Bouwmeester, H. J., \& Beale, M. H. (2004). Enantiospecific (+)- and (-)-germacrene D synthases, cloned from goldenrod, reveal a functionally active variant of the universal isoprenoid-biosynthesis aspartate-rich motif. Archives of Biochemistry and Biophysics, 432(2), 136-144. https://doi.org/10.1016/j.abb.2004.06.030

Quintans, J. D. S. S., Soares, B. M., Ferraz, R. P. C., Oliveira, A. C. a, da Silva, T. B., Menezes, L. R. A, ... Bezerra, D. P. (2013). Chemical constituents and anticancer effects of the essential oil from leaves of Xylopia laevigata. Planta Medica, 79(2), 123-30. https://doi.org/10.1055/s-0032-1328091

Rivoal, A., Fernandez, C., Lavoir, A.-V., Olivier, R., Lecareux, C., Greff, S., ... Vila, B. (2010). Environmental control of terpene emissions from Cistus monspeliensis L. in natural Mediterranean shrublands. Chemosphere, 78(8), 942-949. https://doi.org/10.1016/j.chemosphere.2009.12.047 
Silva, L. da, Oniki, G. H., Agripino, D. G., Moreno, P. R. H., Young, M. C. M., Mayworm, M. A. S., \& Ladeira, A. M. (2007). Biciclogermacreno, resveratrol e atividade antifúngica em extratos de folhas de Cissus verticillata (L.) Nicolson \& Jarvis (Vitaceae). Revista Brasileira de Farmacognosia, 17(3), 361-367. https://doi.org/10.1590/S0102-695X2007000300010

Siqueira, C. A. T., Oliani, J., Sartoratto, A., Queiroga, C. L., Moreno, P. R. H., Reimão, J. Q., ... Fischer, D. C. H. (2011). Chemical constituents of the volatile oil from leaves of Annona coriacea and in vitro antiprotozoal activity. Brazilian Journal of Pharmacognosy, 21(1), 33-40. https://doi.org/10.1590/S010 2-695X2011005000004

Skiri, H. T., Galizia, C. G., \& Mustaparta, H. (2004). Representation of primary plant odorants in the antennal lobe of the moth Heliothis virescens using calcium imaging. Chemical Senses, 29(3), 253-267. https://doi.org/10.1093/chemse/bjh026

Souza, J. G. de L., Toledo, A. G., Santana, C. B., dos Santos, C. V., Mallmann, A. P., da Silva, J. P. B., \& Pinto, F. G. da S. (2017). Chemical composition and antibacterial activity of essential oil and leaf extracts of Zanthoxylum caribaeum Lam. against serotypes of Salmonella. Revista Brasileira de Saude e Producao Animal. https://doi.org/10.1590/S1519-99402017000300005

Stranden, M., Liblikas, I., König, W. A, Almaas, T. J., Borg-Karlson, A-K., \& Mustaparta, H. (2003). (-)-Germacrene D receptor neurones in three species of heliothine moths: structure-activity relationships. Journal of Comparative Physiology. A. Neuroethology, Sensory, Neural, and Behavioral Physiology, 189(7), 563-77. https://doi.org/10.1007/s00359-003-0434-y

Suzuki, N., \& Mittler, R. (2012). Reactive oxygen species-dependent wound responses in animals and plants. Free Radical Biology and Medicine, 53(12), 2269-2276. https://doi.org/10.1016/j.freeradbiomed.2012. 10.538

Van Den Dool, H., \& Kratz, D. (1963). A generalization of the relation index system including liner temperature programmed gas-liquid partition chromatography. Journal of Chromatography A, 11, 463-467. https://doi. org/10.1016/S0021-9673(01)80947-X

Wang, G., Li, X., Huang, F., Zhao, J., Ding, H., Cunningham, C., ... Li, Q. (2005). Antitumor effect of $\beta$-elemene in non-small-cell lung cancer cells is mediated via induction of cell cycle arrest and apoptotic cell death. CMLS Cellular and Molecular Life Sciences, 62(7-8), 881-893. https://doi.org/10.1007/s00 018-005-5017-3

Wang, Y., Owen, S., Li, Q., \& Peñuelas, J. (2007). Monoterpene emissions from rubber trees (Hevea brasiliensis) in a changing landscape and climate: Chemical speciation and environmental control. Global Change Biology, 13(11), 2270-2282. https://doi.org/10.1111/j.1365-2486.2007.01441.x

Yao, Y.-Q., Ding, X., Jia, Y.-C., Huang, C.-X., Wang, Y.-Z., \& Xu, Y.-H. (2008). Anti-tumor effect of $\beta$-elemene in glioblastoma cells depends on p38 MAPK activation. Cancer Letters, 264(1), 127-134. https://doi.org/10.1016/j.canlet.2008.01.049

\section{Copyrights}

Copyright for this article is retained by the author(s), with first publication rights granted to the journal.

This is an open-access article distributed under the terms and conditions of the Creative Commons Attribution license (http://creativecommons.org/licenses/by/4.0/). 